\title{
Considerações sobre teoria, poética e análise da música antiga ${ }^{1}$
}

Considerations about theory, poetics and analysis of ancient music

Cassiano de Almeida Barros 2

Universidade do Estado de Santa Catarina cassianobarros@hotmail.com 


\section{Resumo}

A teoria musical, como categoria de pensamento sobre a música, constitui-se historicamente como conceito representativo das formas consideradas válidas de se conhece-la, diretamente condicionado pela cultura que o produz. No contexto da música antiga, esse conceito esteve associado a outros, tais como a poética e a prática musical, que definiam, conforme finalidades específicas, as possibilidades de realização e compreensão da música. Partindo de uma perspectiva hermenêuti$\mathrm{ca}$, à maneira de um estudo de caso, este artigo apresenta uma investigação sobre o conceito de teoria musical no contexto específico da música luterana seiscentista e avalia a relação dele com os conceitos de poética e análise musical, no marco do tratado intitulado Musica Poetica (1606), de Joachim Burmeister.

Palavras-chave: Teoria musical; poética musical; análise musical; Joachim Burmeister.

\section{Abstract}

Music theory, as a category of thought about music, historically constitutes itself as a representative concept of the ways considered valid to know music, directly conditioned by the culture that produces it. In the context of ancient music, this concept was associated with others, such as poetics and musical practice, which defined, according to specific purposes, the possibilities of making and understanding music. Starting from a hermeneutic perspective, in the manner of a case study, this article presents an investigation about the concept of music theory in the specific context of 17th century Lutheran music and assesses its relationship with the concepts of poetics and music analysis, within the framework of Joachim Burmeister's treatise entitled Musica Poetica (1606).
Keywords: Music Theory. Musical Poetics. Music Analysis. Joachim Burmeister.

A categoria de música antiga é certamente abstrata, constituída para distinguir, de forma genérica, a produção e a prática de uma música mais recente daquela anterior, igualmente como ocorreu com a prima e a seconda pratica, a ars nova e a ars antiqua, por exemplo. A música antiga poderia ser definida em oposição à música nova e original produzida desde o século XIX e continuada ao longo dos séculos XX e XXI, ou ainda remeter àquela música dos séculos XV, XIV, XIII e XII e anterior, incluindo a música referenciada por Guido, Boécio, Agostinho, Quintiliano, Aristoxeno, Platão, Pitágoras e outros. No entanto, neste texto, considero como música antiga aquela produzida, praticada e pensada no contexto do Antigo Regime, ou seja, aquela própria das monarquias europeias dos séculos XVI, XVII e XVIII, tanto católicas quanto protestantes, presente nas sedes dos poderes políticos e religiosos e nas suas diversas ramificações, incluindo estados e colônias mais ou menos periféricas.

Bacharel (2001 - Música - Regência e Cravo), mestre (2006) e doutor (2011) em Música pela Universidade Estadual de Campinas Unicamp. Tem experiência na docência no ensino superior, na formação de músicos e professores de música. Dedica-se principalmente ao ensino e à pesquisa, com ênfase nas áreas da Musicologia, História da Teoria Musical (poéticas antigas e retórica musical), Regência e Educação Musical. Atualmente, desenvolve projeto de pós-doutorado no Programa de Pós-Graduação em Música da Universidade do Estado de Santa Catarina UDESC com apoio da Capes. É autor do livro Uma chave para a música do século XVIII, publicado pela Editora Appris em 2019. 


\section{À guisa de introdução}

Em 2002, a editora da Universidade de Cambridge publicou um livro denominado The Cambridge History of Western Music Theory (A história da teoria da música ocidental de Cambridge), organizado pelo musicólogo americano Thomas Christensen (1954) a pedido da própria editora. De natureza enciclopédica, essa obra reúne ensaios assinados por diversos pesquisadores, dedicados aos mais variados temas atribuídos ao longo da história da música ocidental ao campo da teoria da música. Na introdução dessa obra, que é assinada pelo próprio organizador, Christensen discute a qualidade polissêmica e histórica da teoria musical e constata que, "muitas vezes, concepções amplamente divergentes da teoria da música podem ser encontradas confrontando-se entre si numa mesma cultura histórica, dentro do conjunto da obra de um mesmo escritor e, ocasionalmente, até numa mesma publicação"3 (CHRISTENSEN, 2002, p.1, tradução minha). Por essa razão, ele se questiona se de fato seria possível elaborar uma história de algo tão variado, intelectualmente diverso e conceitualmente instável: "A 'teoria da música' é, em última análise, um objeto histórico inteligível e significativo? ${ }^{4 "}$ (CHRISTENSEN, 2002, p.2, tradução minha).

A resposta para esta questão é afirmativa e se constitui, em parte, na própria publicação organizada por Christensen, nos termos da complexidade daquilo que seus diversos autores apresentam e representam em seus ensaios. Sem a pretensão de esgotar a discussão dos temas propostos, essa publicação registra uma espécie de "estado da arte" das discussões e trabalhos acadêmicos dedicados a cada tema, apresentando uma multiplicidade de referências e apontando caminhos para pesquisas futuras.

Como Christensen nos lembra, os problemas decorrentes de se lidar com a elaboração de uma história da teoria musical não resultam apenas das vicissitudes de rótulos e taxonomias lexicais, mas de se compreender as mudanças ontológicas fundamentais do significado dessa teoria musical (CHRISTENSEN, 2002, p.13, tradução minha). Nesses termos, considera que aquilo que unifica os diversos ensaios que compõem essa publicação talvez sejam, de fato, os diversos dilemas que a própria teoria da música engendra: "[...] uma disciplina que parece se destacar da prática, mas que está inextricavelmente ligada a ela; uma disciplina que afirma transcender a história e é inteiramente histórica" 5 (CHRISTENSEN, 2002, p.21, tradução minha). Para ele, nenhuma dessas tensões pode ou deve ser resolvida, pois são elas que impulsionam o exercício teórico da música.

Pensando a teoria desde uma perspectiva etimológica, ele nos lembra ainda que

[...] a teoria não é apenas um conjunto de ferramentas de observação; essas ferramentas também nos dizem algo sobre quem as usa. Se recordarmos que a raiz latina da "teoria" - speculum - também significa "espelho", podemos começar

\footnotetext{
3 Original: "Widely diverging conceptions of music theory can often be found jostling with one another in the same historical culture, within the oeuvre of the same writer, and occasionally even in the same publication".

$4 \quad$ Original: "Is 'music theory' ultimately an intelligible and meaningful historical subject?".

5 Original: "[...] a discipline that seems to stand apart from practice yet is inextricably tied to that practice; a discipline that claims to transcend history yet is through and through historical".
} 
a entender como as teorias históricas da música atuam como um espelho das culturas intelectuais musicais do passado, nas quais o teórico também é refletido como observador. Pois o próprio ato de reflexão deve necessariamente colocar o interlocutor em uma relação recursiva com o objeto sob escrutínio. Em última análise, não há ponto de observação transcendental, dado que essa reflexão deve sempre ocorrer em uma determinada posição na cultura e no tempo. Uma verdadeira teoria da música, portanto, reflete em ambas as direções, nos dizendo tanto sobre o teórico individual quanto sobre o problema musical em consideração. ${ }^{6}$ (CHRISTENSEN, 2002, p.21, tradução minha).

Além da figura do teórico individual, as teorias nos dizem também algo sobre o lugar social desse indivíduo e as relações que ele guarda com os demais indivíduos que compartilham com ele do mesmo universo cultural. Além dessas questões identificadas por Christensen, podemos ainda considerar outras tantas, que nos permitam por exemplo fazer referência ao contexto da ação do teórico de produzir uma reflexão, às condições de registrá-la e fazê-la circular, que pressupõem a influência das múltiplas referências utilizadas pelo teórico em diálogo, a dinâmica desse diálogo nos termos das possibilidades vigentes para o gênero discursivo que ele opera - seja um tratado, um dicionário, uma carta, um manual, um ensaio etc. - ; o uso que ele faz da linguagem para representar suas ideias, enaltecendo algumas referências em detrimento de outras presentes em seu tempo, quando cumpre o papel social de fazer circular e regulamentar o pensamento sobre a coisa refletida nos termos definidos pela instituição a que serve, cumprindo sua função social no contexto da estrutura social vigente.

O filósofo Pierre Bourdieu (1930-2002), ao tratar sobre os sistemas simbólicos que estruturam e constituem o capital cultural circulante em diferentes sociedades, dá um passo adiante sobre essas questões, quando faz referência à hipótese da gênese social dos esquemas de pensamento, de percepção, de apreciação e de ação que, se associada à divisão social em classes, nos permite estabelecer correspondência entre as estruturas sociais - como estruturas de poder - e as estruturas mentais, por meio da estrutura dos sistemas simbólicos, tais como a língua, a religião, as artes e, dentre elas, certamente a música (BOURDIEU, 2007, p.33). Nesse sentido, a figura do teórico individual de Christensen assumiria os contornos mais amplos de uma figura social, um teórico que constitui o capital cultural que reproduz, nos termos próprios do sistema de símbolos que opera, as estruturas de poder que reafirmam seu lugar social e o lugar dos demais indivíduos de acordo com a maneira com que ele se posiciona em relação à estrutura social vigente. Entre a plena conservação do status quo e sua total ruptura, as posições assumidas configurariam o ato de fazer teoria da música como um ato político. Nesses termos, podemos considerar que esses sistemas simbólicos e seus atores sociais contribuem, em cada momento histórico e contexto cultural,

\footnotetext{
$6 \quad$ Original: "[...] theory is not just a set of observational tools; these tools also tell us something about those who use them. If we recall that the Latin root of 'theory' - speculum - also means 'mirror', we can begin to understand how historical music theories act as a mirror of past musical intellectual cultures, ones in which the theorist too is reflected as an observer. For the very act of reflection must necessarily put the interlocutor in a recursive relation with the object under scrutiny. There is ultimately no transcendental point of observation, given that such reflection must always take place at a given position in culture and time. A true theory of music, then, reflects in both directions, telling us as much about the individual theorist as it does about the musical problem under consideration".
} 
[...] para a imposição (dissimulada) dos princípios de estruturação da percepção e do pensamento do mundo e, em particular, do mundo social, na medida em que impõe um sistema de práticas e de representações cuja estrutura objetivamente fundada em um princípio de divisão política apresenta-se como a estrutura natural-sobrenatural do cosmos. (BOURDIEU, 2007, p.33-34).

Num texto publicado em 1993, Christensen constata a existência de duas grandes categorias que sintetizariam as formas mais recorrentes de abordagem da teoria musical: uma chamada de presentista e outra chamada de historicista. A primeira caracteriza-se pelo estudo de um objeto "à luz dos conhecimentos e normas atuais". É qualificada por ele como míope, em decorrência da aparente dificuldade daqueles que a praticam em enxergar as coisas que estejam além daquilo que suas próprias referências podem lhes mostrar. Ele esclarece:

A teoria da música é declaradamente presentista quando interpreta a música do passado usando ferramentas analíticas e modos de classificação contemporâneos. Muitas críticas literárias formalistas e estruturalistas também podem ser rotuladas como presentistas, na medida em que os textos literários são tratados como objetos autônomos separados de seus contextos históricos e intenções de origem. Talvez a corrente mais notória - e persistente - da historiografia presentista seja a teleologia, na qual o passado é visto como parte de algum processo determinista direcionado para, e culminando em, o presente. Esse processo é geralmente considerado como sendo progressivo, com o julgamento implícito de que o presente está em um estágio de desenvolvimento qualitativamente mais avançado do que o passado7. (CHRISTENSEN, 1993, p.11, tradução minha).

Por essa razão, as teorias do passado, por sua posição na linha do tempo, seriam consideradas menos desenvolvidas, elaboradas, e por isso mesmo mais imperfeitas e inacabadas se comparadas às teorias que as sucederam e aquelas produzidas em nosso tempo presente, por ocuparem a última posição nessa linha, seriam as melhores e mais aptas a responder às questões do teórico de hoje. Assim como a ciência, a teoria musical seria concebida como algo que tivesse evoluído inexoravelmente "em direção a níveis mais altos de sofisticação e verdade, e - dependendo da temeridade do autor - atingindo sua perfeição final em seus próprios escritos"8 (CHRISTENSEN, 1993, p.11, tradução minha).

Já a segunda categoria, a historicista, caracteriza-se pela iniciativa de abordagem do passado conforme os seus próprios termos. Segundo o musicólogo americano,

Para o historicista, o passado é muito variado e complexo para ser reduzido a uma série de momentos dentro de algum processo ou estrutura histórica de-

\footnotetext{
$7 \quad$ Original: "Music theory is avowedly presentist when it interprets music from the past using contemporary analytical tools and modes of classification. Much formalist and structuralist literary criticism can also be labeled as presentist, in that literary texts are treated as autonomous objects severed from their historical contexts and authorial intentions. Perhaps the most notorious - and persistent - strain of presentist historiography is teleology, wherein the past is seen as part of some determinist process directed to, and culminating in, the present. This process is usually considered to be progressive, with the entailed judgement that the present is at a qualitatively more advanced stage of development than the past".

8 Original: "Music theory, like science, was seen as evolving inexorably toward higher levels of sophistication and truth, and - depending upon the temerity of the author - attaining its final perfection in his own writings".
} 
terminista; exige antes ser revelado em sua riqueza e singularidade completas. É por isso que o historicista ortodoxo rejeita toda forma de presentismo na investigação histórica, seja a introdução de padrões contemporâneos de racionalidade ou a sobreposição de modelos estruturalistas e forças históricas idealistas. ${ }^{9}$ (CHRISTENSEN, 1993, p.19, tradução minha).

Nessa condição, o historicista espera que qualquer compreensão do passado seja efetuada de acordo com as referências desse tempo, e não aquelas do tempo presente. Essa abordagem é qualificada por Christensen como ingênua, pois geralmente associa-se à ideia de que seja possível recuperar, de um texto qualquer, seu sentido original, ou a prática original a que ele faz referência, desconsiderando a participação ativa daquele que opera a leitura e execução do texto ou repertório antigo na compreensão daquilo que lê.

Naquele momento, em 1993, Christensen constatou que

[...] vários musicólogos também assumiram posições que se entrecruzam com a agenda historicista. Em geral, são historiadores que duvidam da teoria contemporânea da música por causa de sua péssima tendência ao anacronismo. Isso não significa que esses musicólogos neguem completamente a legitimidade das ferramentas analíticas contemporâneas quando aplicadas à música do passado. Em vez disso, eles argumentam que a música é compreendida de maneira mais significativa no contexto de sua própria cultura e que as teorias musicais coincidentes com a música em consideração têm uma melhor chance de decodificar esses significados culturalmente enraizados do que as teorias presentistas contemporâneas. ${ }^{10}$ (CHRISTENSEN, 1993, p.20, tradução minha).

Ainda que se relativizem ou se flexibilizem as posições assumidas, é fato que uma e outra forma de abordagem das teorias musicais apresentam fragilidades em si mesmas incontornáveis. Por essa razão, Christensen propõe uma terceira via, a abordagem hermenêutica, como uma espécie de reconciliação entre díspares que parte do reconhecimento do lugar daquele que opera a leitura e efetua a compreensão no tempo presente sem negar a importância do passado em seus próprios termos, assumindo a diferença entre ambos como o lugar onde efetivamente se efetua a compreensão.

Citando o filósofo Hans Georg Gadamer (1900-2002), Christensen pondera que

O tempo já não é mais, primariamente, um abismo a ser transposto porque divide e distância [temporal entre o ato da elaboração de um texto no passado e o ato de sua leitura no presente], mas é, na verdade, o fundamento que sustenta o acontecer, onde a atualidade finca suas raízes. A distância de tempo não é, por conseguinte, algo que tenha de ser superado. Esta era, antes, a pressuposição ingênua do historicismo, ou seja, que era preciso deslocar-se ao espírito da épo-

\footnotetext{
$9 \quad$ Original: "For the historicist, the past is too multifarious and complex to be reduced to a series of moments within some determinist historical process or structure; it demands rather to be revealed in its full richness and uniqueness. This is why the orthodox historicist rejects every form of presentism in historical inquiry, whether it be the introduction of contemporary standards of rationality or the superimposition of structuralist models and idealist historical forces".

10 Original: "[...] a number of musicologists have also taken positions that intersect the historicist agenda. For the most part these are historians who are dubious of contemporary music theory because of its baleful penchant for anachronism. It is not that these musicologists altogether deny the legitimacy of contemporary analytical tools when applied to music of the past. Rather, they contend that music is most meaningfully understood in the context of its own culture and that music theories coterminous with the music under consideration have a better chance of decoding such culturally rooted meanings than do contemporary, presentist theories".
} 
ca, pensar segundo seus conceitos e representações em vez de pensar segundo os próprios, e somente assim se poderia alcançar a objetividade histórica. $\mathrm{Na}$ verdade, trata-se de reconhecer a distância de tempo como uma possibilidade positiva e produtiva do compreender. Não é um abismo devorador, mas está preenchido pela continuidade da herança histórica e da tradição, a cuja luz nos é mostrado todo o transmitido. ${ }^{11}$ (GADAMER apud CHRISTENSEN, 1993, p.29, tradução minha).

Em relação a essa abordagem hermenêutica, duas questões básicas devem ser destacadas: 1) não há compreensão fora da linguagem, ou seja, a linguagem é a base ontológica para tudo o que é compreensível e passível de ser expresso (KAHLMEYER-MERTENS, 2017, p.126-127); 2) o próprio objeto da compreensão é linguístico, isto é, não apenas o processo do compreender, mas também o a-ser-compreendido é desde "linguisticidade". Tudo aquilo que se apresenta como compreensível já o é no sentido da linguagem, ou, dito de outra forma, o ser que pode ser compreendido é linguagem; o que não significa que a linguagem seja a base para se compreender a totalidade das coisas, mas apenas que a compreensão só ocorre em relação àquilo que a linguagem possibilita. Nesses termos, apresentam-se as limitações e potencilidades de nossa compreensão, assim como sua materialidade (KAHLMEYER-MERTENS, 2017, p.129-133).

A linguisticidade da teoria musical, assim como da análise, da poética e da prática musical se materializa em seus discursos, produzidos ao longo do tempo, que registram as diversas formas de se pensar, criticar, produzir e praticar as músicas que eles refletem e materializam suas possibilidades de compreensão. Sendo assim, em última instância, poderíamos considerar que o que se destaca na relação entre música e história pode ser justamente a historicidade dos modos particulares de se definir, produzir, consumir e avaliar a música como prática simbólica. Esses modos são historicamente variáveis e cada um deles se associa à maneira como a experiência do tempo histórico é vivida e interpretada por nós hoje, que nos debruçamos sobre textos antigos dedicados à música, e pelos tantos autores do passado, que se dedicaram à produção, ao registro e à circulação desses textos.

No campo da crítica literária, pela perspectiva da justificação do ensino da literatura, o professor João Adolfo Hansen (1942-) afirma existir

[...] uma determinação fundamental, de ordem material e simbólica, na base de qualquer apropriação dos textos literários: sempre há um intervalo entre o ato do autor que inventou a ficção e o ato do leitor que a refaz. Esse intervalo é cronológico, tempo histórico, e semântico, diferença cultural. (HANSEN, 2019, p.16). 
Esse intervalo mencionado pelo Prof. Hansen equivale àquele proposto por Gadamer e assumido por Christensen em sua proposta: ele consiste no espaço da diferença no qual nossa compreensão das coisas se efetua, independentemente dessas coisas relacionarem-se à literatura, à música ou a qualquer outro objeto de conhecimento, pois o que o define é, antes, a distância temporal e cultural que separa os polos da comunicação - o autor e o leitor. Importa ainda destacar, nos termos propostos pelo prof. Hansen, a qualidade material e simbólica desse intervalo. Sua materialidade nos remete ao aqui e agora em que realizamos a leitura e nos lembra de que houve também um aqui e agora em que o texto foi escrito; lembra-nos também da materialidade do suporte utilizado para o registro do texto, tal como o pergaminho, o papel, a tela do computador, a pena, a imprensa, e a forma como esse suporte nos chega hoje, tal como sua versão original, uma edição fac-símile, ou uma edição moderna, ou suas múltiplas formas digitalizadas, ou o hipertexto que pode ter passado "pelas mãos" de diversos editores e revisores antes de chegar até nós; assim como é igualmente material a palavra escrita, que nos chega em sua versão original, ou atualizada, ou traduzida, ou editada, que nos serve de vestígio de um passado morto, a ser ressuscitado por nós, conforme as possibilidades que nosso tempo presente nos fornece. Por sua vez, a natureza simbólica desse intervalo nos atenta para os valores que esse texto representa em seu aqui e agora de origem, que podem ser diversos daqueles que temos em nosso aqui e agora de leitores. Assumo como evidente a ideia de que, em diferentes épocas e contextos culturais, diferentes valores orientaram as práticas sociais e as produções artísticas, e que esses diferentes valores foram representados por diferentes convenções simbólicas. Assim, parafraseando Hansen, podemos dizer que a determinação do próprio conceito de música, por exemplo, em cada época e lugar, implica que sejam especificados os modos históricos e variáveis de definição e funcionamento de categorias como linguagem, arte, teoria, poética, imitação, representação, verossimilhança, composição, compositor, obra, público, poesia, forma, gênero, estilo, figura, valor artístico e muitas outras. Essas categorias não são naturais, e é a sua especificidade que pode ser documento de práticas simbólicas que produziram a música desde a antiguidade até o nosso tempo presente (HANSEN, 2019, p.13).

Como leitores de textos antigos de teoria, análise, poética e prática musical, ao nos situarmos no tempo presente de nossa leitura e reconhecermos os diversos tempos presentes na escrita daquilo que lemos, podemos aprender ainda com Hansen que

[...] o nosso presente de leitores não é o único que há, mas só mais um entre outros, particular e precário como todos, e que está passando e já vai passar e felizmente já passou. A leitura de ficção é, nesse sentido, excelente ocasião para comparar os mundos possíveis que a ficção inventa com o mundo do leitor. Sempre entendi essa comparação como experiência antropológica decisiva que, antes mesmo de propiciar qualquer empatia com os textos, é experiência irônica, que distancia e relativiza, evidenciando a arbitrariedade, a diferença e o efêmero das convenções culturais. Essa experiência da historicidade dos textos como nenhuma substancialidade do tempo, mas experiência do tempo como matéria transformada por um trabalho particular situado e orientado como projeto foi o que sempre tentei evidenciar aos alunos, propondo que talvez pudes- 
sem aprender, na experiência da leitura, o quanto permaneceriam inacessíveis a si mesmos enquanto estivessem dominados pela naturalização e a universalização das crenças e certezas que viviam como verdades transistóricas. Desse modo, poderia dizer que uma das razões de ensinar literatura evidenciando a historicidade dos seus processos de invenção, circulação e consumo era e é política, quero dizer, ensinar literatura para evidenciar o caráter arbitrário da cultura, a nenhuma universalidade das regras sociais, a total contingência das coisas e, com isso, criticar a naturalidade e a normalidade pressupostas nos hábitos. (HANSEN, 2019, p.16-17).

Valho-me aqui do reconhecimento histórico da literatura como arte e, enquanto arte, análoga à música, para propor uma transposição dessas ideias para este outro campo e para reconhecer na abordagem hermenêutica dos textos antigos de música e do repertório musical antigo seu atualíssimo valor político, sua emergente necessidade nos currículos universitários, na pesquisa acadêmica, nos palcos e demais espaços culturais concretos e virtuais que dispomos atualmente. Apoiando-se em Bourdieu, o prof. Hansen justifica assim suas ideias:

Bourdieu o diz bem: historicizar nossa relação com a leitura é uma maneira de nos desembaraçarmos do que a história pode nos impor como pressuposto inconsciente. E não se trata de relativismo, como acusam os adeptos da natureza humana: a historicização é um meio de relativizar a nossa própria prática e, justamente por isso, de escapar da relatividade. Se o que digo sobre a leitura é produto de condições nas quais fui e sou produzido como leitor, diz Bourdieu, o fato de tomar consciência disso é talvez o único modo de escapar do efeito dessas condições. (HANSEN, 2019, p.18).

Nesse ponto, Hansen e Bourdieu aproximam-se da perspectiva hermenêutica de Gadamer proposta por Christensen para as pesquisas relacionadas à história da teoria musical. Em relação ao reconhecimento da participação do leitor - como agente integrante de uma certa tradição, e por isso mesmo portador de preconceitos em relação à coisa lida - na formulação de sua compreensão sobre um texto, Gadamer comenta:

Aquele que não quer conscientizar-se dos preconceitos que o dominam acaba considerando erroneamente o que vem a se mostrar sob eles. [...] A consciência histórica que quer compreender a tradição não pode abandonar-se à forma metódico-crítica de trabalho com que se aproxima das fontes, como se ela fosse suficiente para proteger contra a intromissão dos seus próprios juízos e preconceitos. Verdadeiramente tem que pensar também a própria historicidade. Estar na tradição não restringe a liberdade do conhecer, mas a faz possível. (GADAMER, 1999, p.532).

Nessa perspectiva, Christensen nos alerta de que "é precisamente quando estamos confiantes de que compreendemos o significado de um texto passado, devido à sua ressonância familiar, que ficamos mais vulneráveis ao anacronismo"12 (CHRISTENSEN, 1993, p.30, tradução nossa). Por essa razão, nos lembra que os textos de teoria musi- 
cal nos oferecem inúmeros exemplos de termos e conceitos cujo sentido, ao longo do tempo, foi sendo sutilmente modificado, tais como os conceitos de tonalidade, modo, frase, cadência, e outros, e que, portanto, a leitura de textos antigos de teoria da música não deveria ser feita de forma direta e unívoca (CHRISTENSEN, 1993, p.30).

Nessa perspectiva, recuperamos de Gadamer a ideia de que

A tarefa da compreensão histórica inclui a exigência de ganhar em cada caso o horizonte histórico [que lhe corresponde], a fim de que se mostre, assim, o que queremos compreender em suas verdadeiras medidas. Quem omitir esse deslocar-se ao horizonte histórico a partir do qual fala a tradição estará sujeito a mal-entendidos com respeito ao significado dos conteúdos daquela. (GADAMER, 1999, p.452, 453).

Esse deslocamento a que Gadamer se refere caracteriza-se pelo movimento do leitor em direção ao passado, partindo conscientemente de seu tempo e lugar no presente e promovendo uma fusão de horizontes - aquele do passado do autor e o do presente do leitor - na qual se efetua a compreensão.

Sem qualquer pretensão de esgotar essa reflexão, a fim de colocar esses rudimentos metodológicos em prática, à maneira de um estudo de caso, este artigo apresenta a seguir a investigação sobre os conceito de teoria musical no contexto específico da música luterana seiscentista e avalia a relação dele com os conceitos de análise e poética musical, no marco do tratado intitulado Musica Poetica, publicado por Joachim Burmeister (1566-1629) em Rostock, em 1606. Primeiramente, buscamos compreender a ideia de música vigente no contexto de onde emerge esse tratado, o valor social dela e seus usos, para em seguida avançar em direção ao texto de Burmeister.

\section{O contexto seiscentista luterano e a música}

O movimento protestante promovido por Martinho Lutero (1483-1546) no século $\mathrm{XVI}$ orientou-se originalmente por teses religiosas, mas, pela dimensão que assumiu, acabou por exercer forte influência política e cultural, modificando as estruturas e práticas sociais existentes que, por fim, legitimaram o movimento como uma nova religião (SKINNER, 1996, p.292). A cisão iniciada em 1517 com a Igreja Católica Romana, no centro do continente europeu, ensejou a reformulação de dogmas religiosos, a pactuação de novas alianças políticas e a constituição de novas organizações e práticas sociais, tais como as escolas latinas, o acesso à educação e o protagonismo civil e religioso da população que, orientada pelo princípio do servir (LUTERO, 2017a, p.84), deveria assumir uma postura ativa na manutenção da ordem social e na promoção do bem comum (LUTERO, 2017a, p.22, 24).

De acordo com Skinner (1996, p.292), "a teologia luterana constituiu as estruturas que orientaram o confronto entre o movimento da reforma protestante e o da contrarreforma católica". Essas estruturas surgiram da própria contestação das ideias e princípios católicos, como respostas que negavam princípios e práticas vigentes e instituíam novos, moldando uma nova visão de mundo. Foi a partir dessa visão que se constituíram os princípios políticos que passaram a vigorar nesse novo contexto. 
Conforme a concepção teológica de Lutero, todos os cristãos seriam iguais perante Deus e participariam igualmente do reino espiritual por meio do batismo, do evangelho e da fé. No reino secular, o que distinguiria um sacerdote de um príncipe, senhor, artesão ou camponês seria apenas a função que cada um desempenha no corpo social, que está destinado a preservar a ordem e a paz e a promover o bem comum, pelo exercício mútuo do servir regulado pela conveniência (LUTERO, 2017a, p.83).

Ora, não seria conveniente para a ordem social que todos desempenhassem as mesmas funções, e, por essa razão, alguns se tornariam sacerdotes, outros camponeses, outros músicos, e assim por diante. Nesse sentido, Lutero define o verdadeiro cristão como aquele que "não vive na terra para si mesmo, mas para o próximo e lhe serve. Pela natureza de seu espírito, faz também aquilo que não precisa, mas que é útil e necessário para seu próximo" (LUTERO, 2017b, p.27). Nessa perspectiva, replica nas relações sociais o regime de servidão conveniente que subordina uns aos outros, garantindo a manutenção da estrutura e das funções sociais vigentes.

Nesse contexto, aquele que ocupa o lugar mais elevado na hierarquia social também exerce uma função, assim como todos aqueles abaixo dele, e sua posição na hierarquia social se justificava pelo poder que the teria sido conferido por Deus, reconhecido como a única fonte legítima de poder (LUTERO, 2017b, p.14), aquela autoridade acima da qual nada existe e a cuja vontade todos deveriam se subordinar. Essa figura, denominada por Lutero em um manifesto ${ }^{13}$, de forma genérica, de autoridade secular, representada nos títulos de reis, príncipes, arquiduques e outros, constitui a estrutura social abaixo dela conforme diferentes níveis de divisão de seu poder, neste caso, de natureza exclusivamente secular, constituindo uma rede de interesses e favores que reafirmavam e legitimavam o lugar das posições sociais exercidas. Lutero entendia que a autoridade secular, no exercício da administração do reino temporal, era também "servidora de Deus" e servi-la equivaleria a servi-Lo, posto que "a autoridade é de tal natureza que se pode servir a Deus por meio dela" (LUTERO, 2017b, p.37). Há de se considerar, contudo, que o campo de atuação da autoridade secular é limitado pela condição temporal, material e contingente do mundo em que ela opera, preservando o mundo espiritual para a ordem de Cristo, que é Deus. Essa referência orientava o julgamento da ação cristã no mundo e a obediência à autoridade secular, conforme prescreve Lutero (2017b, p.55). Com relação a isso, Cesca (apud BARBOSA, 2011, p.872) acrescenta que "entre Igreja e Estado haveria uma linha de continuidade, não na sua origem, mas na sua finalidade", e Barbosa pondera que, "apesar de Lutero sugerir competências distintas para Igreja e Estado, ele não os teria separado como instâncias autônomas. O Estado limitava e regulamentava a Igreja enquanto instituição social e esta proclamava a vontade de Deus àquele" (BARBOSA, 2011, p.872). Nesse caso, portanto, o Estado era concebido como uma instituição também cristã, e Lutero não cogitava a secularização dele no âmbito político.

De fato, a Igreja Luterana, concebida como uma comunidade na fé (congregatio fidelium), se constituiria como uma instituição menos verticalizada, ou melhor, mais horizontal, na medida em que reconhecia todos os cristãos num mesmo patamar, subor- 
dinados apenas a Cristo, conhecido pelas Escrituras - a face revelada de Deus - como o único caminho para a Sua graça, única fonte de salvação. Nessa concepção de igreja, todos se igualariam pelo princípio do servir, ainda que esse serviço se diferenciasse, por seu valor social e econômico, em grau de importância, como ocorria na comparação do serviço prestado por um príncipe, um padre e um padeiro, por exemplo. Independentemente de qual fosse o serviço executado pelo membro do corpo social, todos se subordinariam à cabeça, que é Cristo (LUTERO, 2017a, p.84).

A teologia política de Lutero e as doutrinas sociais que ele derivou dela rapidamente obtiveram aceitação oficial numa grande região ao norte da Europa. Segundo Fife (apud SKINNER, 1996, p.302), "as primeiras iniciativas nesse sentido ocorreram na Alemanha, onde o eleitor da Saxônia, Frederico - o Sábio, tomou a iniciativa de proteger Lutero após sua excomunhão, em 1520". Cinco anos depois, esta região se tornou um principado luterano. Nesse mesmo ano, o ducado da Prússia aderiu ao movimento luterano, e, no ano seguinte, a Casa de Hesse. Skinner relata que,

[...] em 1528, a relação dos príncipes germânicos que haviam deixado a igreja católica incluía os duques de Brunswick e Schleswig, o conde de Mansfeld e o margrave de Brandenburgo-Ansbach; em 1534, a eles já se tinham somado os senhores de Nassau, Pomerânia e Württemberg. Várias cidades imperiais também se haviam convertido. Em 1525, os luteranos controlavam Altenburgo, Bremen, Erfurt, Gotha, Magdeburgo e Nuremberg; em 1534, eram igualmente suas Augsburgo, Frankfurt, Hanover e Estrasburgo. (SKINNER, 1996, p.302).

Para que essa nova doutrina religiosa pudesse lograr pleno êxito, Lutero articulou-a com uma ampla reforma educacional, conduzida por Ph. Melanchton (1497-1560), que ficou posteriormente conhecido como professor da Alemanha (Praeceptor Germaniae). Para Lutero, a escola operaria como um instrumento de estado dedicado à formação necessária para o exercício da fé e da vida social (LUTERO, 1995, p.305, 310). Sua manutenção deveria ser responsabilidade do Estado, de modo que se assegurasse igualdade de oportunidades a todos, pelo menos na formação necessária para o acesso às Escrituras.

Além de justificar a necessidade das escolas, Lutero formula proposta de currículo, indicando os conhecimentos necessários para a formação almejada. Esse currículo, de caráter humanista, conforme especifica Cambi (1999, p.250), enfatiza o estudo das línguas antigas (grego, hebraico e latim), as línguas modernas (em particular o alemão), as artes liberais, a história e as ciências. O estudo das línguas é justificado, numa perspectiva cristã, pelo acesso que elas viabilizam às Sagradas Escrituras. Aliás, a palavra, signo da racionalidade humana, é reconhecida por Lutero como um "maravilhoso e nobre dom de Deus", com o qual Ele comunicou seu evangelho, se fez presente entre os homens e é assim preservado, como "bainha da espada do Espírito".

Para Lutero, a escola deveria constituir-se como um espaço dedicado a uma educação atraente, prazerosa e adequada aos jovens. Destaca que

[...] a juventude tem que dançar e pular e está sempre à procura de algo que cause prazer. Nisto não se pode impedi-la e nem seria bom proibir tudo. Por 
que então não criar para ela escolas deste tipo e oferecer-lhe estas disciplinas? [...] Falo por mim mesmo: se eu tivesse filhos e tivesse condições, não deveriam aprender apenas as línguas e História, mas também deveriam aprender a cantar e estudar Música com toda a Matemática. (LUTERO, 1995, p.319).

Lutero atribuiu um lugar de destaque à música em sua proposta de reforma religiosa. Reconhecida como instrumento próprio da ação do Espírito Santo, conforme relatos das Escrituras - como por exemplo em II Reis 3:15 - a música ocupou o lugar seguinte ao da Palavra de Deus, a principal, senão a única fonte de conhecimento Dele. De fato, Lutero reconhecia na música uma origem divina, observando sua presença na natureza como manifestação da "voz" das coisas e considerando que "desde o começo do mundo ela foi infundida e implantada em todas as criaturas, individualmente e coletivamente. Pois nada existe sem som, sem número sonoro" (LUTERO, 1979, p.322).

Ao homem também foi concedida uma voz, um instrumento para a fala e o canto, que deveria ser utilizada principalmente para o conhecimento de Deus e seu louvor, a exemplo dos santos profetas e patriarcas, que produziram

[...] muitos hinos e salmos nos quais a palavra e a música se unem para mover as almas dos ouvintes, enquanto em outros seres vivos e corpos sonoros a música permanece uma linguagem sem palavras. Afinal, o dom da linguagem combinado com o dom da música foi dado apenas ao homem para que ele soubesse que ele poderia louvar a Deus com palavras e música, isto é, proclamar a Palavra de Deus por meio da música e ministrar doces melodias com palavras. (LUTERO, 1979, p.323-324).

Em conformidade com a proposta agostiniana, Lutero concebeu a música como um dom de Deus que, infundido em todos os seres vivos, era considerado o mais apto a transmitir a palavra Dele (LUTERO, 1979, p.322). Ao prefaciar a coleção de motetos intitulada Sinfonias Agradáveis (Symphoniae iucundae), publicada por Georg Rhau em 1538, Lutero distinguiu a expressão musical humana das demais manifestações musicais encontradas na natureza pela associação com a palavra - signo da racionalidade do homem (LUTERO, 1979, p.323-324).

Dessa forma, Lutero condicionou a prática musical de sua igreja à palavra e elevou a música à condição de viva vox evangelii, ou seja, à condição de "voz viva de Deus", o meio mais eficiente de persuadir e educar para o bem supremo (LUTERO, 1979, p.323). Não só por sua natureza divina e seu potencial expressivo Lutero justificou o lugar atribuído à música na sua igreja reformada. Ele reconheceu nela um potencial pedagógico que poderia ser explorado na educação daqueles que a escutam, estudam e executam.

No "Prefácio a todos os bons hinários", escrito por Lutero para introduzir um texto de Johann Walter, de 1538, o reformador especifica o modo de ação da música ao afirmar que ela "silencia e prepara o coração para a palavra e verdade divina" (LUTERO, 2016, p.483). Nesse mesmo texto, Lutero reconhece que "dentre todos os prazeres sobre a terra não há maior que seja dado a alguém do que aquele que eu [a Dona Música] proporciono com meu canto e com certas doces sonoridades" e que "cada qual tem o direito desse prazer não ser pecado, mas, ao invés, agrada a Deus muito mais do que to- 
dos os prazeres do mundo inteiro", pois a música "destrói a obra do diabo e impede que muitos malvados matem" (LUTERO, 2016, p.483). Nesses termos, podemos compreender que o apreço de Lutero pela música fundamenta-se principalmente na justificação religiosa que ela proporciona: "ela destrói a obra do diabo" - infundindo a palavra e a verdade divina por meio do prazer que proporciona, estimulando a fé e constituindo um círculo virtuoso a partir do próprio gosto pela música. Assumindo o autogoverno como exercício da vida cristã, orientado pela autoconsciência de seus deveres, como propôs Lutero, pode-se reconhecer nessa ideia de música seu valor para o aprimoramento da ordem social e do regime político vigente. Nessa perspectiva, podemos também reconhecer o lugar ocupado pela música no currículo escolar e nas práticas de ensino das novas escolas luteranas.

A relação entre as escolas e as igrejas garantiu que a música se constituísse como uma atividade sempre presente na vida escolar, mesmo que em graus variados nas diferentes instituições onde ela acontecia. Aliás, foi a função religiosa da música que viabilizou isso, enfatizando ora sua prática pelo canto, ora sua teoria, "com toda a Matemática", conforme sugerido por Lutero no seu Manifesto de 1524.

De acordo com Butt (1994, p.6), as primeiras ordenanças luteranas determinavam que os livros didáticos deveriam ser tão concisos quanto possível e que, em relação à educação musical, os livros mais comumente utilizados no século XVI foram o Rudimenta musicae (1534), de N. Listenius, e o Compendiolum musicae (1548), de H. Faber. Butt (1994) afirma não ser possível precisar se esses livros foram efetivamente utilizados pelos estudantes, mas, por outro lado, é possível considerar que, por sua circulação, eles formassem a base da instrução dos professores.

Além dessas produções, outras também foram elaboradas, constituindo uma bibliografia específica dedicada ao ensino da música. Dentre elas, Lucas destaca que

[...] os primeiros livros destinados especificamente às escolas luteranas são de autoria de Martin Agricola, que pertenceu diretamente ao círculo de Lutero: Ein kurtz deudsche musica (1528); Musica instrumentalis deudsch (1529); Musica figuralis (1532); Musica choralis (1533), além do Rudimenta Musices (1539). Trata-se de obras voltadas para a prática musical, que apresentam os principais elementos da teoria musical quinhentista: solmização, mutação, tactus, modus, prolação etc. (LUCAS, 2014, p.82).

Essas obras de Agricola, escritas em alemão, claramente refletem a proposta de Lutero que encerra seu Manifesto de 1524, onde se lê:

Por último, recomenda-se a todos aqueles que se interessam pela criação e manutenção de tais escolas e do estudo das línguas na Alemanha, que não se poupem esforços nem dinheiro para a instalação de livrarias ou bibliotecas, especialmente nas grandes cidades que tenham condições para tanto. Pois se quisemos preservar o Evangelho e todas as artes, há que registrá-lo por escrito em livros e ali deve ser fixado (como o fizeram os próprios profetas e apóstolos, como dito acima). E isso não somente para que os príncipes espirituais e seculares tivessem literatura para ler e estudar, mas também para que os livros bons sejam preservados e não se percam juntamente com as artes e línguas que agora temos pela graça de Deus. (LUTERO, 1995, p.322). 
A produção de material didático para as diversas áreas de conhecimento e para a música, em particular, contribuiu para a sistematização do próprio conhecimento em si, sua difusão e conservação. Em relação à música, essa produção bibliográfica constituiu, desde o século XVI, uma vasta coleção de textos publicados dedicados aos principais ramos dessa arte, a saber, o teórico, o prático e o poético.

\section{O campo da teoria, da prática e da poética da música luterana seis- centista}

No tratado Rudimenta Musicae (1534), citado por Butt como um dos textos mais difundidos no universo luterano no século XVI, Listenius define a música como "a arte de cantar bem"14 (LISTENIUS, 1534, p.6, tradução minha) e, como tal, divide-a em dois ramos, o teórico e o prático, que se distinguem por seus fins. Enquanto o primeiro tem como fim o conhecimento, o segundo tem como fim a ação. Na descrição deste segundo ramo, o autor insere uma breve menção à poética, concebida nesse momento como parte da prática, que se destaca dela pela particularidade de seu objetivo, a produção de uma obra cuja existência supera aquela do próprio ato que a produziu ${ }^{15}$ (LISTENIUS, 1534, p.6-7, tradução minha).

Quatro anos mais tarde, Listenius reformulou sua definição e, em seu tratado intitulado Musica, publicado em 1537, definiu-a nesses termos: "Música é a ciência do cantar de acordo com o costume [rite] e bem"16 (LISTENIUS, 1537, p.7, tradução minha). Essa aparente divergência terminológica entre as definições pode ser compreendida desde uma perspectiva agostiniana, tomada como referência nesse contexto luterano tanto para questões dogmático-religiosas quanto para questões musicais. Agostinho de Hipona (354-430) era reconhecido como um dos pais da Igreja Católica, referência fundante da ordem monástica agostiniana, na qual Lutero formou-se religioso. Suas obras exerceram grande influência na origem do movimento protestante e certamente estavam presentes como referência também nos textos sobre música, tema ao qual Agostinho dedicou o diálogo intitulado Sobre a música (De musica). Nesse diálogo, Agostinho define a música como a ciência de modular bem ${ }^{17}$ (AGOSTINHO apud FAGUNDES, 2014, p.187). Ao longo desse texto, o autor considera o termo modular como equivalente ao mover, ou a um determinado tipo de perícia em mover ou, precisamente, aquilo que faz algo se mover bem (AGOSTINHO apud FAGUNDES, 2014, p.189). Ele esclarece: "A modulação se aplica a qualquer cantor que não erre nas medidas das vozes e dos sons"18

\footnotetext{
$14 \quad$ Original: "Musica est ars bene cantandi".

15 Original: "[Musica] Theorica, quae circa ingenii contemplatione \& cognitionem tantum versatur, cuiús finis est scire, hinc theoricus musicus, qui artem novit, verum hoc ipso contentus, nihil de ea scribit, nec docet quemque. [Musica] Practica, quae non solum in ingenii penetralibus delitescit, sed in opus ipsum erumpit, cuius finis est agree, hinc practicus musicus, qui ultra artis cognitionem, ceteros cam docet, atque artis precepta agendo exhibet, ita tamen, ut post actum nihil supersit operis. Poetica sive fabricativa dicitur, quando opus post labore relinquitur, veluti, cum a quoque musica conscribitur".

16 Original: "Musica est rite ac bene cantandi scientia".

17 Original: "Musica est scientia bene modulandi".

18 Original: "Nam modulatio ad quemvis cantorem, tantum qui non erret in illis dimensionibus vocum ac sonorum".
} 
(AGOSTINHO apud FAGUNDES, 2014, p.190). O adjetivo que qualifica positivamente a ação designa o condicionamento dela às leis numéricas, recuperando a relação dessa arte com as demais artes liberais, todas elas dirigidas ao espírito e pertencentes apenas a ele, a sede da razão, que é referida aqui como equivalente à ciência, a um pensamento dirigido que tem sede no espírito (AGOSTINHO apud FAGUNDES, 2014, p.191-192). Nesses termos, podemos considerar a proximidade entre as definições de Agostinho e Listenius, assumindo, entre ambos, a equivalência da ideia de a música constituir-se como uma certa razão do cantar que pode ser positiva quando se orienta, racionalmente, por termos matemáticos, por um lado, e conforme o costume, por outro.

Desta segunda definição, Listenius deriva três ramos distintos da música: o teórico, o prático e o poético. Este último, que em 1534 estava concebido como parte do ramo prático, agora torna-se um ramo independente. Os três são descritos da seguinte maneira:

[A música] teórica é aquela que trata apenas da contemplação pelo engenho e do conhecimento da coisa, e seu fim é o saber. De onde resulta que um músico teórico é aquele que conhece a arte [ars] por si só, e se contenta com isso, sem produzir qualquer coisa em sua atividade. [A música] prática é aquela que não apenas se esconde no interior do engenho, mas no próprio trabalho se apresenta, sem também deixar uma obra após o ato, e seu fim é o agir. De onde resulta que o músico prático é aquele que, além do conhecimento da arte, ensina outros e dessa forma dedica-se ao trabalho de outras pessoas. [A música] poética é aquela que não está contida no conhecimento da coisa e nem na sua prática, mas deixa algo da obra produzida após o trabalho, assim como quando uma música ou um poema musical é escrito por alguém, e nesse caso o fim é a obra perfeita e completa. Pois isso consiste em fazer ou fabricar, ou seja, em um trabalho que deixe depois dele, quando o criador estiver morto, uma obra perfeita e acabada. De onde resulta que o músico poeta é aquele que permanece em algum grau na obra produzida. Esses dois últimos (o prático e o poeta) têm o primeiro (o teórico) perpetuamente ligado a eles, mas não o contrário ${ }^{19}$. (LISTENIUS, 1537, p.7-8, tradução minha).

Chama a atenção a semelhança entre as ideias de Listenius e aquelas formuladas por Aristóteles. Considerando a influência do estagirita no universo luterano a partir das traduções de seus textos efetuadas por Ph. Melanchton, podemos considerar que a relação de suas ideias com as de Listenius seja não apenas verossímil, mas efetivamente possível, na medida em que compunham o universo de ideias circulantes. Em sua Ética a Nicômaco, ao tratar sobre as virtudes dianoéticas, aquelas próprias do pensamento, ou seja, as capacidades de conhecimento da alma racional, Aristóteles define a ciência como o conhecimento dos princípios, ou ainda como um hábito demonstrativo, que torna o demonstrado um objeto de ensino e de aprendizagem (ARISTÓTELES, 2005, p.184-185). A arte, por sua vez, é definida como um certo hábito produtivo com razão e

Original: "[Musica] Theorica est quae in ingenii contemplatione ac rei cognitione tantum versatur, cuiús finis est scire. Unde Theoricus Musicus, qui artem ipsam novit, verum hoc ipso contentus, nullum eius specimen agendo exhibet. Practica, quae non solum in ingenii penetralibus delitescit, sed in opus ipsum prodit, nullo tamen post actum relicto opera, cuius finis est agere. Unde practicus Musicus, qui ultra artis cognitionem ceteros docer, eaque se citra alicuius operis effectum exercet. Poetica que necque rei cognitione, necque solo exercitio contenta, sed aliquid post laborem relinquit operis, veluti cum a quopiam Musica, aut musicum carmen conscribitur, cuiús finis est, opus consumatum \& affectum. Consistit enim in faciendo sive fabricando, hoc est, in labore tali, qui post se etiam, artifice mortuo, opus perfectum \& absolutum relinquat, Unde Poeticus musicus, qui in negotio aliquid relinquendo versatur. Et habent hae duae posteriores sibi perpetuo coniunctam superiorem, sed non e contra". 
cujo princípio está em quem produz, e não naquilo que é produzido. Finalmente, a prática consiste num hábito acompanhado de verdadeira razão e cujo fim é a perfeição do próprio agir (ARISTÓTELES, 2005, p.185, 187). Em todas as capacidades de conhecimento, a razão acompanha ativamente a consecução de um fim específico: o saber, o agir e o produzir. Numa perspectiva metafísica, Christensen sintetiza a concepção aristotélica nos seguintes termos: a teoria dedica-se ao conhecimento das causas finais, isto é, da razão de existir das coisas; a prática, ao conhecimento das causas formais, ou seja, do modo assumido pelas coisas, e a poética, ao conhecimento das causas eficientes, ou seja, daquilo que dá origem às coisas (CHRISTENSEN, 2002, p.3).

Com a metafísica aristotélica, lembramos também que, por sua natureza, todos os homens tendem ao saber; que os homens adquirem ciência e arte por meio da experiência e que a arte resulta de muitas observações da experiência, como um juízo geral e único passível de ser referido a todos os casos semelhantes (ARISTÓTELES, 2002, p.3). Assim, esclarece Aristóteles, a experiência constitui-se como o conhecimento de muitos particulares, ao passo que a arte se constitui como o conhecimento dos universais (ARISTÓTELES, 2002, p.5). Porém, destaca que todas as ações e as produções se referem ao particular, pois situam-se, justificam-se e configuram-se na contingência das circunstâncias em que ocorrem. Por fim, conclui que, "se alguém possui a teoria sem a experiência e conhece o universal, mas não conhece o particular que nele está contido, muitas vezes errará o tratamento (como um médico a seu paciente), porque o tratamento se dirige, justamente, ao indivíduo particular" (ARISTÓTELES, 2002, p.5). Desde essa perspectiva, podemos compreender os termos que encerram a definição da poética musical de Listenius, que compreende o músico prático e o músico poeta "perpetuamente" ligados ao músico teórico, na medida em que o exercício do ato e da produção musical não pode prescindir do conhecimento da teoria da música, enquanto o teórico, que se contenta apenas com o universal, pode prescindir dos demais.

Além das ideias aristotélicas e agostinianas, compõe também a "visão de mundo" de Listenius a concepção de música de Boécio (ca. 480-524), com a qual podemos compreender, em parte, a distinção entre o músico teórico, o prático e o poeta que ele reproduz em sua definição. Em relação a Boécio, Umberto Eco afirma:

Com Boécio, verifica-se um fato muito sintomático e representativo da mentalidade medieval. Ao falar de música, Boécio entende uma ciência matemática das leis musicais; o músico é o teórico, o conhecedor das regras matemáticas que governam o mundo sonoro, enquanto o executante é frequentemente apenas um escravo sem perícia, e o compositor é um instintivo que não conhece as belezas inefáveis que só a teoria pode revelar. Só quem julga ritmos e melodias à luz da razão pode ser chamado músico. (ECO, 2010, p.66).

Ainda que a distância temporal e cultural entre Boécio e Listenius seja grande e que as distinções propostas pelo primeiro para as categorias de músicos não possam ser transpostas literalmente para o segundo, alguns aspectos os aproximam, e, dentre eles, podemos destacar: 1) a compreensão da metafísica como uma forma válida de leitura do mundo, que fundamenta a própria constituição dessas categorias e daquilo que elas 
representam; 2) a divisão de classes, que se relaciona a uma divisão do trabalho, do poder e do conhecimento, e que estabelece diferentes funções e níveis sociais e objetos de conhecimento também diversos para cada indivíduo, conforme o lugar que ocupa na estrutura social vigente.

O texto de Listenius não trata da teoria musical para além de sua definição, mas, por meio dela, e considerando outros tratados contemporâneos ao seu, compreendemos que ela era dedicada ao desenvolvimento da concepção pitagórica da música, formulada por Boécio e difundida pelo currículo escolar formado pelas artes liberais. Aqui, porém, cabe um esclarecimento: entre as artes liberais, a música tem dupla inserção uma, de primeira ordem, como disciplina do Quadrivium dedicada ao conhecimento do mundo pelo número aplicado (multitudo ad aliquid), conforme perspectiva pitagórico-boeciana; e outra, de segunda ordem, como composição elocutiva (compositio) operada pela retórica e pela poética - ambas disciplinas do Trivium -, que orienta a constituição dos discursos de acordo com a sonoridade das palavras. Enquanto a primeira inserção constitui aquilo que se convencionou chamar de musica theorica, a segunda inserção constitui boa parte do que se convencionou chamar de musica practica e de musica poetica. Neste segundo caso, a relação da música com a palavra constitui "boa parte" da prática e da poética musical, mas não a sua totalidade, certamente, porque somam-se aos elementos oriundos da palavra, matriz e matéria do cantar, os elementos próprios da ação e da produção musical, tais como as técnicas instrumentais e de contraponto, por exemplo, que não faziam parte do currículo escolar liberal.

No currículo escolar formulado pela ocasião de formação das escolas latinas luteranas, a ênfase do conhecimento musical desvia-se do ramo teórico e recai sobre os ramos poético e prático, acompanhando a tendência humanista de valorização das línguas (BURKE, 2003, p.40-47, 94). Além disso, há de se considerar, em relação a esses tratados de Listenius, que eles foram elaborados para a instrução musical elementar de estudantes de nível básico do projeto escolar luterano, que valorizava a prática e a poética musical também como forma de acesso às Escrituras e como exercício de fé. Nessa perspectiva, o conhecimento teórico assumiria um valor secundário e ficaria restrito aos estudos de nível superior ou a projetos escolares particulares.

Esta ênfase da prática e da poética da música nos currículos escolares se fez notar também nas publicações que foram dedicadas a esse contexto de formação, que constituíram, de acordo com a proposição de Lutero, uma espécie de tradição e corpo de conhecimento legitimados pelas instituições e agentes sociais que se dedicaram a formulá-lo, sistematizá-lo, publicá-lo e difundi-lo. Constituem essa tradição os textos já citados de Listenius, Faber e Agricola, e também os textos de G. Dressler, S. Calvisius, J. Burmeister, J. Lippius, J. Nucius e J. Thuringus, por exemplo, para citar apenas alguns, a título de ilustração. Dentre eles, J. Burmeister é aquele que se reconhece como o primeiro a constituir um vocabulário próprio para tratar de aspectos da poética musical. No prefácio de seu primeiro tratado, intitulado Hypomnematum musicae poeticae (Resumo das observações sobre a poética musical), publicado em Rostock em 1599, Burmeister esclarece: 
Também possibilitei que aqueles elementos que são especiais e notáveis nesta arte [a poética], que até então careciam de nomes próprios, por assim dizer, recebessem seus nomes para que nosso discurso, destinado a esclarecer as coisas por meio de comparação, não pudesse resultar ineficaz por falta de terminologia. ${ }^{20}$ (BURMEISTER, 1993, p.218-219, tradução minha).

Além do autorreconhecimento, Burmeister recebe o reconhecimento alheio, manifestado em duas cartas de endosso da publicação de seu tratado que seguem o referido prefácio. Na primeira delas, assinada por J. Simonius, professor de oratória da Universidade de Rostock, lemos: "Embora eu não afirme nem pretenda fazer juízo sobre a poética musical, tanto quanto posso entender, vejo que, com o que é conhecido como rótulos e termos gramaticais e oratórios, ele cobre erudita e engenhosamente assuntos muito úteis"21 (in BURMEISTER, 1993, p.220-221, tradução minha). Na segunda, assinada por S. Olthoff, vice-reitor da escola de Rostock, Burmeister é reconhecido como aquele que "apresenta todos os elementos por meio de termos adequados e convenientes da disciplina da retórica e outras artes, de modo que poucos erros e dúvidas resultem da ambiguidade das palavras"22 (in BURMEISTER, 1993, p.222-223, tradução minha).

Ao prefaciar seu segundo tratado, intitulado Musica autoschediastike (Compilação improvisada sobre música), publicado em Rostock em 1601 - que se configura como uma espécie de revisão ampliada do primeiro -, Burmeister retoma essa mesma questão que parecia lhe ser de grande valor:

Em todas as áreas da música, certos termos foram formulados para o bem dos meus discípulos, de modo que as coisas serão ensinadas com referência a esses termos, e a discussão será baseada em comparação para que a matéria em discussão seja compreendida e a mente não seja suspensa na ignorância por causa de alguma declaração ou observação ambígua e obscura sobre algo. Somos destituídos de vocabulário, e nossa única razão para inventar novos termos é que podemos aliviar essa deficiência o máximo possível. A autoridade de Quintiliano, registrada no livro 8, capítulo 3 de sua Instituição Oratória, nos encoraja com as seguintes palavras: "Muitas palavras novas e de vários tipos foram cunhadas baseadas no grego etc., nas quais não vejo razão alguma por que as reneguemos tanto, a não ser que nós, juízes, sejamos exagerados conosco mesmos e, por isso, incidamos em pobreza de linguagem". Eu penso que, dada a ordem e o contexto, nossas ideias sobre as coisas da música podem, de forma apta, apropriada e conveniente, ser ajustadas, representadas e combinadas com tais termos e rótulos. Se, ao compilar esses termos, nós não satisfizermos aos especialistas, nós thes pediremos que levem em conta o fato de que nós estamos apenas começando esse estudo, essa obra e esforço. Nós nunca esperamos que a compilação desses preceitos fosse ser fácil, mas o tempo irá nos ensinar

20 Original: "In arte hac praecipua et nobilia sunt hactenus velut proprio nomine orbata, quomodo iisdem nomina dari possint, ne sermo ob penuriam nominum ad rem ipsam collatione explicandam incassum suscipiatur, ansam praeberem".

21 Original: "Etsi enim mihi non tribuo neque arrogo iudicium de musica poetica, tamen quantum ego intelligo, video illum vocibus et terminis, ut vocant grammaticis et oratoriis, res utilissimas erudite et subtiliter complexum esse....

22 Original: "[...] tum accurratis divisionibus cognoscendos proponis, verum etiam omnia aptis et convenientibus vocabulis, ex rhetorum officina, allisque artibus desumptis, enuntias, ut eo minor in vocum ambiguitatibus exista terror et haesitatio". 
e guiar. [...] Logo chegará o tempo em que essa terminologia estabelecerá na mente as raízes dos conceitos e ideias que ela representa e os salvará da inutilidade de sua antiguidade. ${ }^{23}$ (BURMEISTER, 1993, p.236-239, tradução minha).

Aqui, Burmeister constata uma aparente falta de vocabulário musical para tratar das questões de natureza elocutiva que ele desenvolve em seu texto. De fato, não encontramos terminologia específica dedicada a essas mesmas questões em publicações anteriores às dele. Diante dessa "pobreza de linguagem", seguindo a recomendação de Quintiliano, constitui então uma terminologia, transpondo vocabulário do campo da retórica para o da música, ressignificando os termos selecionados conforme as estruturas e procedimentos musicais que eles passam a designar. Este processo, nos lembra Bourdieu, ocorre entre os diversos campos que coexistem num determinado contexto histórico e resulta no compartilhamento de conceitos e modos de pensamento comuns, derivados de propriedades gerais características do próprio contexto que os interliga. As relações de permuta linguística entre esses campos devem ser pensadas "como outros tantos mercados que se especificam segundo a estrutura das relações entre os capitais linguísticos ou culturais dos interlocutores ou dos seus grupos" (BOURDIEU, 1989, p.68-69). Assim, reconhecemos que a própria (re)construção desses objetos de conhecimento exige e fundamenta a transferência conceitual e terminológica entre campos, conforme as homologias estruturais estabelecidas, eliminando de sua compreensão a ideia descontextualizada da metáfora meramente explicativa.

Nesses termos, ao proceder a permuta terminológica entre os campos da Retórica e da Música, constituindo um vocabulário musical, Burmeister recorre às homologias estruturais entre esses campos, estabelecendo "na mente" de seus leitores as raízes dos conceitos e das ideias que essa terminologia representa. Ao dar nome a coisas antes inominadas, Burmeister amplia as possibilidades de percepção e racionalização delas, constituindo um modo "luterano" de perceber e pensar a música que se alinha à tendência também luterana de ampliação e qualificação do acesso à educação como forma de se promover o exercício da fé e a boa manutenção do estado. Nessa perspectiva, recuperamos aqui aquela ideia de Bourdieu já citada anteriormente, de que a música e a religião, assim como a música da religião e outros sistemas simbólicos, contribuiriam para

[...] a imposição (dissimulada) dos princípios de estruturação da percepção e do pensamento do mundo e, em particular, do mundo social, na medida em que impõe um sistema de práticas e de representações cuja estrutura objetivamente

\footnotetext{
23 Original: "Essent quoque auditoribus in forma illa de omnibus ferme rebus, quas musica tractat, certi termini formati, ad quos res cognoscendo perciperentur, et sermo deinde in collatione formaretur, et res, de quibus sermo fit illico intelligerentur, nec mens ex alterius dicti vel enuntiationis de re aliqua ambiguae et obscurae suspensa teneretur. In terminis inveniendis causam habuimus nullam, nisi ut vocabulorum, quibus destituebamur, penuriam pro nosse et posse sublevaremos. Unde factum est, et opus fuit, horum novitatem ut introduceremus. Instigavit autem Quintiliani nos autoritas lib. 8. cap. 3 Institutionis Oratoriae incorporata, quae his verbis sic notatur: 'Multa ex Graeco formata sunt etc. quae cur tantopere aspernemur, nihil vídeo, nisi quod iniqui iudices adversus nos sumus, ideoque sermonis paupertate laboramos.' Quibus terminis sicut et appellationibus, ordine et denique contextus serie non inepte, non inconvenienter, non incommode musicalium rerum notitiam conciliari, suppeditari, et comparari posse arbitramur. In quibus coacervandis, si peritissimis non satisfecimus, concedatur, quaeso, nobis incipientibus studium, operam et laborem mostra ita posita esse. Ad quae nos facilitas, qua praeceptionum harum collectio praedita fore non tam existimabatur, quam dies quandoque docebit, adduxit. [...] Quandoquidem nihil sit tam difficillimum, quod non labor superet et vincat, et novitas hoc secum ferat, ut citius earum rerum, quas suppeditat, cognitionis et notitiae radices in mente agat, quam quae ob antiquitatem vilescunt".
} 
fundada em um princípio de divisão política apresenta-se como a estrutura natural-sobrenatural do cosmos. (BOURDIEU, 2007, p.33-34).

Nesses termos, podemos considerar que os textos dedicados às teorias, poéticas e práticas musicais financiados pela igreja ou os estados luteranos operam, para além da própria educação musical, como instrumentos de ação política e religiosa que definem as possibilidades de leitura do mundo, conforme as convenções estabelecidas e autorizadas pelas instituições sociais então vigentes.

O terceiro tratado de Burmeister, intitulado Musica Poetica (Poética musical), publicado em Rostock em 1606, constitui-se como a última revisão e ampliação das duas publicações anteriores. Neste texto, a preocupação em justificar a proposta de uma nova terminologia já não é tão evidente, ainda que se faça presente de forma genérica no conjunto das preocupações que mobilizam o autor, ou seja, dos problemas que ele procura solucionar. Nesse sentido, no prefácio dessa terceira publicação, Burmeister assevera:

Por isso, acontece forçosamente que, se qualquer um de seus aspectos for negligenciado, a arte não será completamente comunicada. Ou então, com certeza, se não alocarmos espaço para os preceitos necessários, ou se não estivermos dispostos a reconhecê-los, a arte não será totalmente aprendida e haverá um sinal inconfundivel de inveja ou negligência. Pois em toda arte isso ou aquilo tem que ser de um jeito ou de outro. Mas se alguém não menciona e explica por que algo deve ser assim e não o contrário, por que isso deve ser observado e aquilo ignorado, por que isso é louvável e digno de imitação ao passo que aquilo é censurável e deve ser evitado, então para o que, eu pergunto, isso deve ser atribuído, se não ao ciúme? De fato, se uma coisa é ensinada a alguém, como ela pode resultar em algo contrário às regras? Pois, se forem ignoradas, ninguém pode negar que haverá inevitavelmente muitos resultados errados, impróprios e censuráveis. [...] É por causa deles [aqueles que não respeitam e reconhecem o valor das regras da arte] que a música está em grande parte aberta a um veredicto injusto de desprezo, e está agora (infelizmente) sujeita a ele. A fim de resgatar a música desse destino lo desprezo decorrente de sua prática desregrada e descompromissada] tanto quanto eu pudesse - pois, após longa consideração e atenção aos pedidos de Deus, eu compreendi que essa arte pode ser mais amplamente comunicada -, eu não hesitei em escrever esses preceitos com a ajuda Dele e em organizá-los numa ordem precisa para o benefício de minha audiência24. (BURMEISTER, 1993, p.4-7, tradução minha).

Neste tratado, que é dedicado principalmente à poética musical, uma questão que parece mobilizar seu autor é o aparente desprezo pelas regras da arte entre estudantes ou, talvez, seu desconhecimento, resultante da falta de textos que promovam o tipo de formação que ele propõe. Desse modo, Burmeister responde àquilo que ele descreve

\footnotetext{
24 Original: "Unde hoc consequenter necessum fit, ut Ars, si ejus aliqua pars praetermittitur, integre non communicetur; aut certe si praeceptis necessarijs locum non damus, nec ea cognoscere volumus, non plene percipiatur, et non leve vel invidenriae, vel socordiae signum subsit. Nam cum in Arte sit hoc vel illud, quod sic se habet, vel minus; idipsum autem cur ita fiat, cur non; cur item hoc observandum, illud negligendum; cur hoc laudabile sit et ad imitandum aptum, illud vituperabile et fugiendum, si reticetur, nec cuiquam revelatur, cui, quaeso, praeter invidiam, sit tribuendum? Et certe si tandem alicui idipsum monstratur, quomodo praeter morem id praeceptionum fieri potest? Hae vero si ignorantur nemo negabit necesse esse, ut multa perperam, multa non decore, multa vituperio digna fiant. [...] Quorum gratia haec Ars iniquae contemptus sorti non leviter exposita est, et etjamnum subjecta esse (proh dolor) cogitur. A quo, quoad fieri, et quoad a me aliquid opis huc accedere potest, ut vindicetur, haec praecepta, quantum Deo suggerente jam longa observatione notavi posse hanc Artem plenius communicari, eodem cooperante conscribere, et in accuratioris ordinis formam redigere, ac ad Auditorum meorum placitum edere non detrectavi [...]".
} 
como um chamamento divino para salvar a música desse descaminho e qualifica seu trabalho pela ajuda que diz ter recebido de Deus. Isso, por um lado, indica ao leitor o valor de seu trabalho e, por outro, situa o próprio autor no contexto social do qual participa, pelo serviço prestado. Além disso, por ter sua obra autorizada para publicação pelas instituições locais, Burmeister seria reconhecido como aquele que, naquele local, recebeu a autorização para dizer, em nome dessas mesmas instituições, como a música deveria ser percebida, pensada e produzida, constituindo-se como uma autoridade nesses assuntos. Sinal disso são os sete poemas escritos por autoridades de Rostock que acompanham o prefácio de seu texto, todos em estilo elevado e dedicados ao seu louvor e de sua obra, reconhecendo publicamente seu valor como autoridade nesse assunto.

Burmeister inicia seu tratado com a definição da poética musical nos seguintes termos:

A poética musical, que Euclides chama de melopoeia, que seria o tratamento harmônico de um assunto, com a finalidade de adornar os argumentos de acordo com o que se trata, é aquela parte da música que ensina a compor o poema musical, unindo sons melódicos em harmonia, ornamentados com diversos afetos de períodos, a fim de mover as almas e os corações humanos. ${ }^{25}$ (BURMEISTER, 1993, p.16-17, tradução minha).

Nessa definição, Burmeister dá um passo adiante em relação a seus antecessores, associando a poética musical ao conceito grego de melopoeia, que, segundo Pereira, define a relação entre poesia e música, assumindo a origem da segunda na primeira, na medida em que a música "não preexiste independentemente da palavra, mas antes radica nela, inspira-se e brota a partir dela, constituindo ambas [música e poesia] um todo designado por melopoeia - composição melódica" (PEREIRA, 2001, p.18). Nessa combinação, a forma de uso da linguagem verbal condiciona a forma de uso da música, pelo princípio do decoro, conforme se adornam "os argumentos de acordo com o que se trata" (BURMEISTER, 1993, p.16, tradução minha). Nesses termos, podemos considerar que a palavra aplicada em sentido próprio, em textos simples, de cunho didático, por exemplo, comportaria música igualmente simples, ao passo que à palavra aplicada em sentido figurado equivaleria uma música proporcionalmente figurada, desviada do uso simples e comum. Essas medidas de uso da linguagem, que determinam seu grau de elaboração e figuração, assim como os modos em que esses graus são representados, seja por meio de palavras e/ou sons musicais, são convenções que qualificam as aparências de verdade consideradas válidas no contexto em que se realizam. É nesse sentido que Burmeister faz referência à junção de "sons melódicos em harmonia", circunscrevendo seu discurso à produção da música polifônica, textura própria do estilo vigente, que se caracteriza pela combinação de várias melodias simultâneas, que soem de maneira harmoniosa, conforme as regras do contraponto. Igualmente, podemos tomar a ornamentação da música com diversos afetos de períodos, algo que não aparece nas definições anteriores da poética musical e que pode ser entendido aqui como os desvios da for-

\footnotetext{
25 Original: "Musica Poetica, quam Euclides melopoeia nominat, definitque esse usum harmonicae tractationi subectorum, ad decorum propositi argumenti, est illa musicae pars, quae carmen musicum docet conscribere, coniungendo sonos melodiarum in harmoniam, variis periodorum affectionibus exornatam, ad animos hominum cordaque in varios motus flectenda".
} 
ma mais simples de expressão, empregadas conforme processo analógico próprio que relaciona o gesto sonoro ao seu efeito no ouvinte, como forma de potencializá-lo no âmbito da apresentação de uma ideia completa, ou seja, no âmbito de um período. Esses afetos se materializariam no discurso musical na forma de figuras de expressão, ou seja, formas particulares de representação de ideias que, nas palavras de Burmeister, "se distanciam da razão composicional simples para assumir e vestir, com virtude, um caráter de ornamento"26 (BURMEISTER, 1993, p.154-155, tradução minha). Nesse sentido, os afetos de períodos seriam as figuras empregadas pelos compositores para representar o sentido do texto nessas unidades gramático-retórico-musicais, os períodos. Em relação à causa final da produção musical, que consiste na promoção do movimento das almas e dos corações humanos, podemos dizer que, nesse contexto luterano, o movimento resultante da persuasão deveria orientar ações virtuosas e a elevação da alma, constituídas em hábitos por sua repetição e frequência (cf. ARISTÓTELES, 2005, p.74, 77, 79, 107, $308,309)$. Esses hábitos, por sua vez, contribuiriam para a edificação moral dos indivíduos de acordo com as determinações religiosas e para a manutenção da ordem social que, na concepção luterana, é também de natureza religiosa.

O tratado Musica Poetica é formado por dezesseis capítulos, cada um deles dedicado a um aspecto da produção musical, na seguinte ordem:

\begin{tabular}{|l|l|}
\hline Capitulo & Conteúdo \\
\hline 1. Notação & $\begin{array}{l}\text { Elementos de representação gráfica da música: pentagrama, } \\
\text { claves, letras do alfabeto, acidentes, valores ritmicos, figuras } \\
\text { de pausas, ponto de aumento, equivalência entre formas de } \\
\text { representação e tipos de conversão de uma para outra. }\end{array}$ \\
\hline 2. As partes vocais & $\begin{array}{l}\text { Os tipos de vozes e suas características, semelhanças e } \\
\text { diferenças. }\end{array}$ \\
\hline $\begin{array}{l}\text { 3. Instrução sobre sons } \\
\text { consonantes e dissonantes }\end{array}$ & $\begin{array}{l}\text { O sistema de sons, suas categorias e os tipos de relação entre } \\
\text { eles, as consonâncias e seus tipos e as dissonâncias. }\end{array}$ \\
\hline $\begin{array}{l}\text { 4. A combinação de } \\
\text { consonâncias em harmonia }\end{array}$ & $\begin{array}{l}\text { Sintaxe musical (contraponto); definição de melodia; definição } \\
\text { de harmonia; descrição das possibilidades de conjugação } \\
\text { sonora, do processo de sintaxe, das leis da sintaxe. }\end{array}$ \\
\hline 5. Cadências & $\begin{array}{l}\text { Definição de cadência; descrição dos tipos de cadências e suas } \\
\text { características. }\end{array}$ \\
\hline 6. Os modos musicais & $\begin{array}{l}\text { Definição de modo; descrição dos tipos de modos, da } \\
\text { constituição dos modos e de suas características definidoras. }\end{array}$ \\
\hline 7. A transposição dos modos & Definição de transposição; descrição dos tipos de transposição. \\
\hline $\begin{array}{l}\text { 8. O método para se começar } \\
\text { uma obra de música }\end{array}$ & $\begin{array}{l}\text { Descrição das qualidades que deve ter o começo de uma música; } \\
\text { das razões poéticas para se proceder o início de uma música. }\end{array}$ \\
\hline $\begin{array}{l}\text { 9. O fim de melodias e } \\
\text { harmonias }\end{array}$ & Descrição dos tipos de finalização, suas qualidades e seus usos. \\
\hline $\begin{array}{l}\text { 10. A aplicação do texto na } \\
\text { partitura }\end{array}$ & $\begin{array}{l}\text { Descrição dos critérios para alinhamento do texto com as figuras } \\
\text { musicais. }\end{array}$ \\
\hline 11. Ortografia & Definição de ortografia e critérios de realização. \\
\hline $\begin{array}{l}\text { 12. Ornamentos musicais ou } \\
\text { figuras }\end{array}$ & $\begin{array}{l}\text { Definição de ornamento; descrição dos tipos de ornamento; } \\
\text { descrição das espécies de ornamento. }\end{array}$ \\
\hline
\end{tabular}

26 Original: "Ornamentum sive figura musica est tractus musicus [...] qui a simplici compositionis ratione discedit, et cum virtute ornatiorem habitum assumit et induit". 


\begin{tabular}{|l|l|}
\hline $\begin{array}{l}\text { 13. Os gêneros de canções ou } \\
\text { melodias }\end{array}$ & $\begin{array}{l}\text { Definição de gênero melódico; descrição dos tipos de gênero } \\
\text { melódico. }\end{array}$ \\
\hline 14. Tipos de polifonia & Definição de polifonia; descrição dos tipos de polifonia. \\
\hline $\begin{array}{l}\text { 15. Análise ou disposição de } \\
\text { uma peça de música }\end{array}$ & $\begin{array}{l}\text { Definição de análise; descrição das categorias analíticas; } \\
\text { exemplo de análise. }\end{array}$ \\
\hline 16. Sobre a imitação & $\begin{array}{l}\text { Definição de imitação; descrição dos tipos de imitação; } \\
\text { discriminação de modelos para imitação; descrição dos gêneros } \\
\text { de estilo. }\end{array}$ \\
\hline
\end{tabular}

Quadro 1: Descrição dos capítulos e respectivos conteúdos que compõem o tratado Musica Poetica (1606) de J. Burmeister. Fonte: Elaboração própria.

Considerando este tratado como a última versão de um texto publicado, utilizado e revisado ao longo de pelo menos sete anos, podemos compreendê-lo como a forma final das instruções que, acreditamos, pudessem ser efetivas tanto como prescritivas do processo criativo, para os aspirantes ao exercício da composição, quanto como descritivas, para os ouvintes, desse mesmo processo e, portanto, como chave de leitura e compreensão das obras musicais.

Em relação a essa efetividade, Burmeister recupera aquela perspectiva aristotélica já citada anteriormente, relativa à relação da arte com a teoria e a experiência prática para afirmar:

\begin{abstract}
A fé me move a tratar do tema [a poética musical] apresentando preceitos, puxando minha orelha e me lembrando de que nenhuma arte liberal pode ser transmitida a alguém sem regras. Ela [a fé] me move a me abrir e a fazer crer que com ou sem a ajuda da natureza, imitação e prática, qualquer um pode elaborar uma compreensão da arte, uma vez que esteja amparado por um compêndio. De outra forma, natureza, imitação e prática, desacompanhadas dos textos instrucionais, não são capazes de conduzir ao domínio daquelas coisas que pertencem à arte, e nem a mestria será alcançada na falta de regras que eu considero essenciais a todo compêndio. A menos que sejam formuladas regras precisas, a arte para a qual a instrução é elaborada não será minimamente produzida, e assim ninguém alcançará um perfeito domínio dela27. (BURMEISTER, 1993, p.4-5, tradução minha).
\end{abstract}

Nesses termos, e considerando o longo processo de formulação desse tratado, podemos concluir que ele se apresentava ao público seiscentista como um conjunto efetivo de "regras precisas" que possibilitariam alcançar o "perfeito domínio" da arte, desde que acompanhado de "natureza, imitação e prática". Na tradução da Instituição Oratória de Quintiliano, elaborada por Jeronymo Soares Barboza - professor da Universidade de Coimbra -, publicada em 1788, a natureza é definida como a tendência do indivíduo/orador da qual depende a "evolução" das faculdades de sua alma e de seu corpo. Pelas faculdades da alma, entende "um engenho rico, uma fantasia viva, uma memória feliz e um gosto delicado", e pelas faculdades do corpo, "um peito forte, uma voz

\footnotetext{
27 Original: "Fides, quae in ijs requiritur, qui Artem in manus sumunt explanandam, me concitavit, ut praeceptis id certis praestarem, aures meas vellens et admonens nullam Artem Liberalem sine praeceptis tradi posse ulli, ut ut natura quemque imitatione et exercitio, vel si non, compendio tamen ipsam arripere posse mihi persuaderi paterer. Dum ne natura, imitatio, et exercitatio ad fastigia rerum, quae in Arte tractantur, sine artificii documentis contendere possint; imo ne id, in quo compendii illius rationem consistere arbitrer, praeceptionibus careat, imo etjam, quod in arte minimum est, de quo institutio suscipitur, nisi formatio ex certis de eo praeceptis sumatur, non percipi, ita nec artis praesidia quisquam habere possit perfecta".
} 
clara, suave e sonora e uma figura não desagradável". Imitação e prática, na perspectiva de Barboza, integram-se pelo estudo, definido como "todo o gênero de aplicação, com que o homem trabalha sobre aquele fundo das disposições naturais para as dirigir, aumentar e aperfeiçoar. Tal é o conhecimento das regras, e método, a lição, e imitação dos Oradores, o Exercício etc." (BARBOZA in QUINTILIANO, 1788, p.31). No texto anônimo intitulado Retórica a Herênio, "a mais remota arte retórica escrita em latim que a Antiguidade nos legou e uma das obras antigas de maior circulação na Idade Média" (FARIA; SEABRA in RETÓRICA..., 2005, p.11), o autor especifica a imitação como aquilo "que nos estimula, com método cuidadoso, a que logremos ser semelhantes a outros no dizer". O exercício, por sua vez, é definido como "a prática assídua e o costume de discursar" (RETÓRICA..., 2005, p.55), que, no campo da música, pode ser compreendido como o costume de escrever, compor e executar as obras musicais. De forma análoga, Burmeister define a imitação como "o estudo e o esforço em imaginar e moldar nossos poemas musicais conforme os exemplos de artifícios, que devem ser habilmente examinados por meio de análise"28 (BURMEISTER, 1993, p.206-207, tradução minha).

Nessa proposta, a análise musical se insere como instrumento próprio da formação poético-musical, inicial e continuada, orientada pelo princípio da imitação, conforme a exigência cultural de conservação das formas de representação instituídas pela tradição, historicamente consolidadas como formas eficientes de se (re)produzir as aparências de verdade consideradas válidas e adequadas, por convenção, àquilo que representam. É por meio da análise, segundo Burmeister, que se colocam em evidência os artifícios com os quais cada uma das partes de um discurso musical foi produzida, a fim de estudá-los e tomá-los como modelo para imitação (BURMEISTER, 1993, p.200-201). Para este Kantor, as referências que delimitam esse regime de representação constituem-se de matéria de natureza secular ou religiosa, composta de forma modal e polifônica, como aquela produzida pelos compositores que são apresentados como modelos ou autoridades em relação a determinados tipos de causas, devido ao publicamente reconhecido e recorrente sucesso em cumpri-las. Dentre esses compositores, destacam-se Orlando di Lasso, Clemens non Papa, Ivo de Vento, Alexander Utendal, Luca Marenzio, Jacob Meiland, Antonio Scandello, André Pevernage, Johann Dressler ${ }^{29}$ e outros (BURMEISTER, 1993, p.208-209).

A análise do repertório produzido por esses compositores produziria o conhecimento de muitos bons particulares que, somado ao conhecimento dos universais preceituados por Burmeister, à natureza do compositor e ao exercício da imitação e da prática, conduziriam àquilo que se entendia, então, como uma boa formação poética. De outro modo, o conhecimento dos universais, somado à natureza e ao exercício da execução amadora e da apreciação constantes, conduziriam àquilo que se entenderia

\footnotetext{
28 Original: "Imitatio est studium et conamen mostra carmina musica ad artificum exempla, per analysin dextre considerata, effingendi et formandi".

29 Conforme indica Rivera (in BURMEISTER, 1993, p. 208-209), Ruhke sugere que "Johaness Dresserus" possa ser o compositor Gallus Dressler, autor do tratado intitulado Praecepta Musicae Poeticae (Preceitos de poética musical), documento manuscrito, datado de 1563, dedicado ao ensino da composição musical.
} 
como a formação de um bom público, algo que, ainda que nunca plenamente alcançado, pelo menos funcionaria como objetivo a ser perseguido, na medida em que a educação musical era inserida no currículo escolar. Neste caso, a ideia do bom público corresponderia à ideia de um coletivo social capaz de perceber e compreender o discurso musical como um enunciado significativo, portador de uma mensagem institucional de reafirmação e conservação dos valores sociais vigentes.

\section{Considerações finais}

Os discursos da teoria da música antiga são discursos de natureza filosófica, que espelham a realidade corrigindo-a e que, sendo filosóficos, num dado momento, se tornaram também teológicos, pois assumiram o compromisso com o conhecimento dessa realidade como o conhecimento da presença de Deus no mundo e além dele. Sua leitura pressupõe o reconhecimento da existência de uma metafísica, que essa teoria reproduz como chave de leitura. Nesse sentido, essa teoria da música antiga, se é que isso pode ser tratado como uma categoria genérica, difere-se diametralmente das teorias musicais modernas, como aquelas de P. Hindemith (1895-1963) e A. Schoenberg (18741951) e H.-J. Koellreutter (1915-2005), por exemplo, de que se ocupam os estudantes brasileiros de música hoje, relacionadas com as possibilidades de notação musical, as regras de harmonia e contraponto ou ainda as técnicas de composição.

Esse conhecimento de que tratam as teorias musicais de hoje corresponderia, em sua natureza, ao conhecimento próprio das práticas e poéticas antigas, tal como a de Burmeister, por exemplo, e sua integração ao conhecimento especulativo, filosófico, ocorreria apenas a partir do século XVI, conforme algumas iniciativas de natureza humanista, tal como a de G. Zarlino (1517-1590) em sua obra intitulada Le istitutioni harmoniche (Instituições Harmônicas), de 1558. Antes disso, conforme Boécio e Agostinho, a teoria musical é conservada como objeto de estudo e atividade filosófica, destinada apenas aos homens livres, e não àqueles que se dedicavam à composição e à execução musical, consideradas formas de trabalho especializado e, por isso mesmo, mecânico e servil. Depois disso, a teoria musical se torna saber técnico e prático, poético e estético, como propõem J. G. Sulzer (1720-1779), H. C. Koch (1749-1816), A. B. Marx (1795-1866) e tantos outros. Entre um extremo e outro, a transição se realiza por diversas mãos e ideias, dentre as quais as de E. Kant (1724-1804) e G. W. F. Hegel (1770-1831), associadas às revoluções social, política, econômica, científica, filosófica e cultural que emergem no continente europeu a partir da segunda metade do século XVIII.

Nesses termos, podemos compreender as teorias da música antiga como construções simbólicas, como conjuntos de ideias representativas de visões particulares de mundo, que thes cobram seu sentido. Por sua vez, o conhecimento notacional, modal, contrapontístico, estilístico e figurativo é um conhecimento utilitário, poético, que não tem um fim em si mesmo, como o conhecimento teórico e especulativo, mas se justifica por sua utilidade nos processos produtivos. Desse modo, esse conhecimento técnico opera pela lógica de seus fins, ou seja, é teleológico, e cobra seu valor pelos processos 
que engendra, pelos resultados que gera e pelo sucesso das causas a que se destina. Em cada momento histórico, opera com categorias próprias de produção e recepção, orientando-se retoricamente e constituindo, por meio da emulação, uma tradição que estabelece, para cada causa específica e uso particular, as aparências de verdade possíveis, ou seja, os verossímeis válidos. Um discurso musical verossímil pressupõe sempre a existência do conjunto dos regimes de verdade que uma determinada sociedade acredita. É nesse sentido que se afirma a existência de autoridades, de músicos reconhecidos pelo sucesso recorrente no cumprimento de determinado tipo de causa, como a religiosa de estilo elevado, ou a camerística de estilo médio, ou a teatral de estilo baixo, ou qualquer outra baseada nos usos comuns da linguagem musical.

O conhecimento dos muitos particulares, da maneira com que cada compositor resolve as dificuldades e problemas que se the apresentam na produção de cada obra e de cada gênero discursivo, era construído por meio do exercício analítico, concebido como parte integrante da formação poética, como prescreve Burmeister. A análise musical, no contexto da música antiga, atendia à solução de uma única questão, presente em vários tratados dedicados à poética musical, que seria: de que maneira esta obra cumpre seus objetivos?

Esse repertório antigo é sempre um produto social datado que põe em cena representações sonoras das normas sociais em esquemas expressivos que regulam o ato da execução, e, conforme nos lembra Hansen, essas normas, esquemas e atos já são, como estruturas simbólicas, intepretações que também têm a sua história (HANSEN, 2019, p.19) e que precisam igualmente ser recuperadas.

Ainda que a divisão da música em seus ramos teórico, poético e prático, conforme proposta por Burmeister, nos possibilite (re)conhecer as especificidades da divisão do conhecimento, o próprio conhecimento em si, a consequente divisão do trabalho, as condições institucionais em que esses diferentes trabalhos ocorrem, os instrumentos de trabalho utilizados por aqueles que os realizam, seus materiais e técnicas, o lugar e prestígio social dedicados a cada um desses trabalhadores, será na integração de todos esses elementos que conseguiremos vislumbrar a sombra desse passado que nos chega em ruínas e compreendê-lo hoje, assumindo nosso próprio papel nesse processo de compreensão. Integram-se a isso as divisões do conhecimento musical que praticamos hoje, as diversas divisões do trabalho individual e coletivo que empreendemos, as condições de trabalho que temos, os lugares institucionais em que o realizamos, as questões teóricas, técnicas, instrumentais e materiais envolvidas em sua realização. Tudo isso coloca em perspectiva nossa ação de pesquisa e nosso movimento em direção ao passado, deixando claro que qualquer ação empreendida e resultado obtido serão sempre parciais, incompletos, imperfeitos e inacabados, mas nem por isso desnecessários. Pelo contrário, é a partir dessa constatação que podemos fazer avançar as pesquisas e o conhecimento que elas produzem. 


\section{Referências Bibliográficas}

ARISTÓTELES. Metafísica. São Paulo: Loyola, 2002.

ARISTÓTELES. Ética a Nicómaco. Madrid: Alianza, 2005.

BARBOSA, Luciane Muniz Ribeiro. Estado e Educação em Martinho Lutero: a origem do direito à educação. Cadernos de Pesquisa, São Paulo, v. 41, n. 144, p. 866-885, dec. 2011. Disponível em: http://www.scielo.br/scielo.php?script=sci_arttext\&pid=S0100$15742011000300012 \&$ lng=en\&nrm=iso. Acesso em: 10 abr. 2020.

BOURDIEU, Pierre. O poder simbólico. Lisboa: Difel, 1989.

BOURDIEU, Pierre. A economia das trocas simbólicas. São Paulo: Perspectiva, 2007.

BURKE, Peter. Uma história social do conhecimento I: de Gutenberg a Diderot. Rio de Janeiro: Zahar, 2003.

BURMEISTER, Joachim. Musical Poetics. New Haven; London: Yale University Press, 1993.

BUTT, John. Music Education and the Art of Performance in the German Baroque.

Cambridge: Cambridge University Press, 1994.

CAMBI, Franco. História da Pedagogia. São Paulo: Fundação Editora da Unesp, 1999.

CHRISTENSEN, Thomas. Music Theory and its histories. In: HATCH, C.; BERNSTEIN, D. W. Music theory and the exploration of the past. Chicago: The University of Chicago Press, 1993. p. 9-39.

CHRISTENSEN, Thomas (ed.). The Cambridge History of Western Music Theory. Cambridge: Cambridge University Press, 2002.

ECO, Umberto. Arte e beleza na estética medieval. Rio de Janeiro: Record, 2010.

FAGUNDES, Claudiberto. De musica: diálogo filosófico de Agostinho de Hipona (354430) - introdução, tradução e notas. 2014. 386 p. Tese (Doutorado) - Instituto de Letras, Universidade Federal do Rio Grande do Sul, Porto Alegre, 2014.

GADAMER, Hans Georg. Verdade e método: traços fundamentais de uma hermenêutica filosófica. Petrópolis: Vozes, 1999. 
HANSEN, João Adolfo. Aula magna. [S. l.]: Zazie, 2019. Disponível em: https://static1. squarespace.com/static/565de1f1e4b00ddf86b0c66c/t/5ccba966ec212d9f4f565

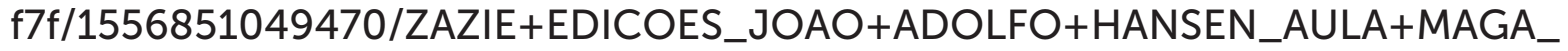
PEQUENA+BIBLIOTECA+DE+ENSAIOS+2019.pdf. Acesso em: 2 fev. 2020.

KAHLMEYER-MERTENS, Roberto S. 10 Lições sobre Gadamer. Petrópolis: Vozes, 2017.

LISTENIUS, Nikolaus. Rudimenta musicae. Wittenberg: Georg Rhau, 1534. Disponível em: http://nbn-resolving.de/urn:nbn:de:gbv:3:1-159413. Acesso em: 30 abr. 2020.

LISTENIUS, Nikolaus. Musica. Wittenberg: Georg Rhau, 1537. Disponível em: https:// www.loc.gov/item/41018759. Acesso em: 28 abr. 2020.

LUCAS, Mônica. Emulação de retóricas clássicas em preceptivas da musica poetica. Opus, Porto Alegre, v. 20, n. 1, p. 71-94, jun. 2014.

LUTERO, Martinho. Preface to Georg Rhau's Symphoniae lucundae. In: LEHMANN, Helmut. Luther's Works: Liturgy and Hymns. V. 53. Philadelphia: Fortress Press, 1979.

LUTERO, Martinho. Aos Conselhos de Todas as Cidades da Alemanha para que criem e mantenham escolas cristãs. In: LUTERO, Martinho. Obras selecionadas. V. 5. São Leopoldo: Sinodal, 1995. p. 302-325.

LUTERO, Martinho. Prefácio a todos os bons hinários. In: LUTERO, Martinho. Obras Selecionadas: vida em comunidade. V. 7. São Leopoldo: Sinodal, 2016. p. 483-484.

LUTERO, Martim. Da autoridade secular. São Leopoldo: Sinodal, 2017a.

LUTERO, Martinho. À nobreza cristã da nação alemã acerca da reforma do estamento cristão. In: LUTERO, Martinho. Martinho Lutero: uma coletânea de escritos. São Paulo: Vida Nova, 2017b. p. 79-92.

PEREIRA, Aires Manuel R. dos Reis. A Mousiké: das origens ao drama de Eurípedes. Lisboa: Fundação Calouste Gulbenkian, 2001.

QUINTILIANO, M. Fabio. Instituicoens Oratorias. Coimbra: Imprensa Real da Universidade de Coimbra, 1788. Disponível em: https://books.google.com.br/ books? id=_OUBAAAAMAAJ\&. Acesso em: 12 abr. 2020.

RETÓRICA a Herênio. São Paulo: Hedra, 2005.

SKINNER, Quentin. As fundações do pensamento político moderno. São Paulo: Companhia das Letras, 1996. 